\title{
KEMAMPUAN PROFESIONAL GURU DAN MOTIVASI KERJA TERHADAP KINERJA MENGAJAR GURU SEKOLAH DASAR
}

Oleh:

Ratika Sari Dewi, Taufani C. Kurniaitun, Abubakar

Universitas Pendidikan Indonesia

(email : Ratika444@gmail.com)

\begin{abstract}
ABSTRAK:
Fokus masalah dalam penelitian ini adalah bagaimana kondisi deskriptif kinerja mengajar guru, kemampuan profesional dan motivasi kerja guru, serta seberapa besar pengaruh kemampuan profesional dan motivasi kerja terhadap kinerja mengajar guru Sekolah Dasar di Kota Cimahi. Metode yang digunakan adalah metode deskriptif dengan pendekatan kuantitatif yang didukung dengan studi dokumentasi serta angket sebagai alat pengumpulan data. Lokasi penelitian ini di Sekolah Dasar Kota Cimahi dengan sampel guru dijadikan sebagai responden penelitian. Hasil penelitian ini menggambarkan bahwa bahwa kemampuan profesional guru berpengaruh positif terhadap kinerja mengajar guru sebesar $39,9 \%$ dan motivasi kerja guru berpengaruh positif terhadap kinerja mengajar guru sebesar $61,7 \%$ serta secara bersamasama kemampuan profesional dan motivasi kerja berpengaruh terhadap kinerja mengajar guru sebesar $63,7 \%$. Rekomendasi yang diajukan adalah Kinerja mengajar guru: hendaknya guru meningkatkan perencanaan pembelajaran dengan baik, kemampuan profesional: hendaknya guru mengikuti seminar, pelatihan maupun workshop yang diadakan oleh sekolah, motivasi kerja: hendaknya guru berusaha untuk selalu menumbuhkan semangat kerjanya di sekolah.
\end{abstract}

Kata Kunci: Motivasi Kerja, Kemampuan Profesional Guru, Kinerja Mengajar Guru

\section{ABSTRACT}

The focus of the problem in this research is how the descriptive condition of teacher's teaching performance, professional ability and work motivation of teacher, and how much influence of professional ability and work motivation on teaching performance of elementary school teacher in Cimahi City. The method used is descriptive method with quantitative approach supported by documentation study and questionnaire as data collection tool. The location of this research is in Cimahi City Primary School with teacher sample as research respondent. Based on the results of the analysis of research data can be concluded that the professional ability of teachers has a positive effect on teacher teaching performance of $39.9 \%$ and (teacher work motivation positively affect teacher's teaching performance of $61.7 \%$ and the same professional skills and work motivation affect the teacher's teaching performance of $63.7 \%$. The recommendations proposed areTeacher teaching performance: teachers should improve learning planning well, professional ability: teachers should attend seminars, trainings and workshops organized by schools, work motivation: teachers should always.

Keywords: Professional Ability, Teacher teaching performance, Work Motivation.

\section{PENDAHULUAN}

Pendidikan merupakan salah satu kunci awal menuju kesuksesan suatu bangsa. Seperti yang terkandung dalam tujuan pendidikan UndangUndang Nomor 20 tahun 2003 tentang Sistem Pendidikan Nasional Pasal 3 bahwa tujuan pendidikan nasional adalah mengembangkan potensi peserta didik agar menjadi manusia yang beriman dan bertakwa kepada Tuhan Yang Maha Esa, berakhlak mulia, sehat, berilmu, cakap, kreatif, mandiri, dan menjadi warga negara yang demokratis serta bertanggung jawab. Hal tersebut adalah suatu usaha menyiapkan sumber daya manusia yang berkualitas, oleh karena itu kualitas pendidikan di Indonesia harus selalu ditingkatkan. Peningkatan kualitas pendidikan tentunya harus didukung dengan adanya peningkatan kualitas tenaga kependidikannya. Guru merupakan tenaga kependidikan yang memiliki tugas utama untuk mendidik, mengajar, melatih, serta mengarahkan peserta didik agar memiliki kesiapan dalam menghadapi persaingan global yang semakin ketat dengan bangsa lain. Oleh karena itu kedudukan guru sebagai tenaga profesional sangatalah penting dalam terwujudnya visi dan misi dalam pembelajaran.

Untuk menjadi guru yang profesional harus memiliki beberapa kompetensi. Dalam undang-undang Guru dan Dosen No.14/2005 dan Peraturan Pemerintah No.19/2005 dinyatakan bahwa kompetensi guru meliputi kompetensi kepribadian, kompetensi pedagogik, kompetensi profesional dan kompetensi sosial. Semua kompetensi tersebut harus dimiliki oleh seorang guru dalam melakukan kegiatan mengajar di sekolah. Guru yang profesional senantiasa dapat meningkatkan kualitasnya. Oleh karena itu seorang guru harus mampu menguasai kompetensi tersebut 
sehingga peserta didik dapat dengan mudah menyerap ilmu yang didapatkan.

Guru yang berkualitas dapat dilihat dari kinerja mengajarnya oleh karena itu kinerja mengajar guru merupkan hasil yang dicapai oleh seorang guru dalam mencapai tujuan sekolah. Hasil kerja guru dapat dilihat dari tanggungjawabnya dalam menjalankan amanah, profesi yang diembannya, serta moral yang dimilikinya, yang tercermin dari kepatuhan, komitmen dan loyalitasnya dalam mengembangkan potensi peserta didikserta memajukan sekolah. (Priansa, D.J, 2014: 79). Kualitas dari kinerja mengajar guru tidak terlepas dari pencapaian hasil belajar. Oleh karena itu kinerja mengajar guru sangat menentukan keberhasilan proses belajar yang efektif dan efisien sehingga tujuan pendidikan dapat tercapai dan terwujud dari hasil belajar siswa yang dapat mencetak lulusan yang berkualitas.

Kinerja guru berpengaruh terhadap kualitas sekolah salah satunya yaitu dari hasil akreditasi. Dari data yang didapatkan dari Dinas Pendidikan Kota Cimahi tahun 2017 bahwa dari 125 sekolah dasar negeri dan swasta bahwa sekitar 34\% sekolah sudah ber-akreditasi A dan sekitar $65 \%$ sudah berakreditasi B. Dan untuk sekolah yang ber-akreditasi $\mathrm{C}$ tidak ada atau $0 \%$. Dari data yang di dapatkan Dinas Pendidikan Kota Cimahi dari Ujian Akhir Sekolah Dasar di kota Cimahi 5 tahun terakhir angka kelulusannya mencapai $100 \%$ walaupun belum mencapai hasil yang diinginkan karena berdasarkan nilai yang diperoleh siswa nilainya tidak terlalu tinggi. Hasil Ujian Akhir Nasional pada tahun 2014/2015 terdiri dari 3 mata pelajaran yaitu Bahasa Indonesia, Matematika, dan IPA dengan nilai rata-rata adalah 21,23 dan pada tahun 2015/2016 terdiri dari 3 mata pelajaran yaitu Bahasa Indonesia, Matematika, dan IPA dengan nilai rata-rata adalah 21,78 sedangkan pada tahun 2016/2017 dari 3 mata pelajaran Bahasa Indonesia, Matematika dan IPA rata-rata nya adalah 22,7 mengalami peningkatan dan menempati peringkat 20 dari 27 kota yang terdapat di Jawa Barat.

Dilihat dari guru yang terdaftar di Dinas Pendidikan Kota Cimahi berjumlah 2.217 terdiri dari jumalah guru sekolah dasar Kecamatan Cimahi Selatan 859 guru, kecamatan Cimahi Tengah 734 guru, Kecamatan Cimahi Utara 354 guru. Sekitar 92\% dari jumlah guru tersebut sudah memenuhi syarat untuk mengajar karna sudah berkualifikasi pendidikan sarjana (S1) dan $8 \%$ jumlah guru berkualifikasi pendidikan S2 dan lebih. Sedangkan guru yang belum layak mengajar tidak ada atau $0 \%$.
Guru sebagai tenaga kependidikan yang profesional menetapkan apa yang baik untuk siswa berdasarkan pertimbangan profesinya, tinggi rendahnya mutu pendidikan yang berlangsung di suatu sekolah tergantung dari derajat profesionalisme yang dimiliki oleh para guru. Sadar akan hal tersebut maka sekolah berlombalomba untuk meningkatkan mutu guru yang dimilikinya (Pupuh dan Suryana, 2012: 25). Guru yang profesional dibuktikan dari kompetensi yang dimilikinya. Guru yang kompeten dapat dibuktikan dengan perolehan sertifikasi guru dan tunjangan profesi yang memadai. Data dari Dinas Pendidikan Kota Cimahi tahun 2017 bahwa sertifikasi guru sekolah dasar kota Cimahi yang sudah tersertifikasi berjumlah 1.060 guru yaitu 48\%, sedangkan yang belum sertifikasi berjumlah 1157 guru yaitu 52\%

Dari wawancara dengan salah seorang pengawas sekolah dasar kota Cimahi bahwa analisis pemerintah Kota Cimahi terhadap hasil uji kompetensi guru (UKG) menunjukkan sejumlah kelemahan profesional guru. Kelemahan terutama terlihat dalam kekurangmampuan sejumlah guru dalam mempersiapkan pembelajaran aktif dan membuat lembar kerja dengan pertanyaan tingkattinggi yang mampu menantang daya kreasi dan kemampuan akademik siswa. Kualitas guru di Cimahi relatif bagus tapi belum merata, sehingga hasil UKG relatif rendah.

Kurangnya kinerja guru di Kota Cimahi salah satu faktor penyebabnya adalah karena kota Cimahi kebanyakan guru sekolah dasar yang sudah memasuki usia pensiun, sebagai diungkapkan oleh Kepala Dinas Pendidikan Kota Cimahi dalam wawancara di Pemkot kota Cimahi bahwa kurangnya tenaga kependidikan guru sekolah dasar di Kota Cimahi kekurangan 350 guru oleh karena itu masih diketemukannya rasio guru berbanding murid lebih banyak dibandingkan dengan idealnya 1:27 di lapangan masih banyak diketemukan 1:30 sampai 1:40.

Kinerja yang optimal merupakan harapan semua pihak namun kenyataan dilapangan menunjukkan masih ada beberapa guru yang kinerjanya belum optimal. Berdasarkan wawancara dengan salah satu guru dan kepala sekolah Sekolah Dasar di kota Cimahi terlihat bahwa kinerja mengajar guru dirasakan masih belum memuaskan. Dalam realitas sehari-hari masih diketemukan antara lain: 1) pembuatan RPP belum optimal bahkan hanya copy paste perangkat tahun lalu, 2) kurangnya kemauan guru menciptakan pembelajaran yang variatif, 3) masih ada guru yang terlambat mengumpulkan adminitrasi guru, 4) kurangnya kedisiplinan seperti 
masih diketemukan adanya guru pulang lebih cepat pulang dari wakatu yang ditentukan dan datang terlambat, 5) Mengeluh dengan kondisi yang dirasakan. Belum optimalnya kinerja mengajar guru tersebut bukan tanggung jawab sekolah saja, melainkan tanggung jawab bersama antara pihak Depdikanas dan Pemerintah.

$\begin{array}{ccc}\begin{array}{c}\text { Peningkatan kemampuan profesional } \\ \text { dapat dikembangkan melalui }\end{array} & \text { kompetensi }\end{array}$ profesional yang dilakukan oleh guru. Tujuan kemampuan profesional guru untuk membantu guru dalam memperluas pengetahuan, meningkatkan keterampilan mengajar guru, menumbuhkan sikap profesional dalam pembelajaran. Oleh karena itu sekolah yang dapat dilakukan oleh pengawas, kepala sekolah maupun antar guru, maka dari itu diselenggarakannya seminar atau workshop, pelatihan atau diklat, kursus-kursus, pendidikan formal yang tinggi serta pembinaan dan pengembanagan untuk mendukung pembelajaran yang efektif untuk meningatkan kemampuan profesional guru.

Motivasi kerja guru merupakan faktor yang sangat penting dalam mempengaruhi kinerja mengajar guru untuk mencapai tujuan pendidikan. Menurut Hamzah. B. Uno (2006: 64) bahwa motivasi adalah munculnya dorongan untuk mencapai tujuan yang ingim dicapai. Dengan demikian semakin tinggi motivasi seseorang maka semakin tinggi pula kinerjanya begitu pula sebaliknya, semakin rendah motivasi seseorang maka semakin rendah pula kinerjanya. Apabila para guru mempunyai motivasi kerja yang tinggi, mereka akan terdorong dan berusaha meningkatkan kemampuannya dalam merencanakan, melaksanakan, dan mengevaluasi kurikulum yang berlaku disekolah sehingga memperoleh hasil kerja yang maksimal.

Salah satu berhasil atau tidaknya sekolah yaitu dengan adanya motivasi kerja guru. Menurut Purwanto (1998: 71) bahwa fungsi motivasi bagi manusia adalah: 1) sebagai motor penggerak bagi manusia, 2) menentukan arah perbuatan yakni ke arah perwujudan suatu tujuan atau cita-cita, 3) mencegah penyelewengan dari jalan yang harus ditempuh untuk mencapai tujuan, dalam hal ini makin jelas tujuan maka makin jelas pula bentangan jalan yang harus ditempuh, 4) menyeleksi perbuatan diri artinya menentukan perbuatan mana yang harus dilakukan yang serasi guna mencapai tujuan dengan menyampingkan perbuatan yang tidak bermanfaat bagi tujuan itu.

Untuk mengetahui bagaimana Pengaruh kemampuan Profesional guru dan Motivasi Kerja terhadap Kinerja Mengajar Guru, penulis memilih jenjang pendidikan di Sekolah Dasar untuk diteliti karna guru sekolah dasar merupakan ujung tombak keberhasilan dalam membentuk generasi bangsa maka dari itu peneliti lebih memfokuskan penelitian pada jenjang Sekolah Dasar. Kota Cimahi adalah sebuah kota di Provinsi Jawa Barat, Kota ini terletak di tengah Kabupaten Bandung dan Kabupaten Bandung Barat yang perkembangannya sangat pesat. Kota Cimahi terdiri dari 3 kecamatan yaitu kecamatan Cimahi Utara, Cimahi Tengah, dan Cimahi Selatan. Kota Cimahi selalu berusaha untuk meningkatkan kualitas pendudukya melalui peningkatan pendidikan formal. Adapun jumlah sekolah dasar sebanyak 125 sekolah terdiri dari kecamatan Cimahi Selatan terdiri dari 47 sekolah, kecamatan Cimahi Tengah 41 sekolah, dan kecamatan Cimahi Utara 37 Sekolah. Walaupun demikian dalam proses belajar mengajar, tentunya masih banyak kekurangan-kekurangan yang masih perlu untuk ditingkatkan. Alasan peneliti mengambil populasi sekolah dasar di Kota Cimahi yaitu kurang nya guru di Kota Cimahi, satu kelas guru terdiri dari 30-40 siswa khususnya SD Negeri idealnya satu guru berbanding 27 siswa.

\section{A. Kinerja Mengajar Guru}

Guru merupakan profesi yang memerlukan keahlian khusus dan juga merupakan tenaga professional yang memberikan pelayanan yang baik kepada siswa tertuang dalam Undang-undang Republik Indonesia No 14 tahun 2005 tentang Guru dan Dosen bahwa guru adalah pendidik profesional dengan tugas utama mendidik, mengajar, membimbing, mengarahkan, melatih menilai, dan mengevaluasi peserta didik pada pendidikan usia dini, pendidikan dasar, dan pendidikan menengah. Dalam Undang-undang No 14 tahun 2005 dijelaskan bahwa guru memunyai kedudukan sebagai tenaga profesional pada jenjang pendidikan usia dini, pendidikan dasar dan pendidikan menengah, pada jalur pendidikan formal yang diangkat sesuai dengan peraturan perundang-undang. (Pasal 2 UU RI No 14:2005).

Kinerja guru menurut Hudarta (2007: 13) yaitu bahwa kinerja guru dalam pembelajaran menjadi bagian terpenting dalam mendukung terciptanya proses pendidikan secara efektif terutama dalam membangun sikap disiplin dan mutu hasil belajar siswa. Dengan demikian guru sangat menentukan mutu pendidikan, berhasil tidaknya suatu pembelajaran, tercapainya tujuan pendidikan dan pembelajaran, terorganisasi kannya sarana dan prasarana, peserta didik, media, alat dan sumber belajar. Kinerja guru merupakan kemampuan seorang guru dalam melaksanakan tugas pembelajaran di sekolah dan bertanggung 
jawab atas peserta dibawah bimbingannya dengan meningkatkan prestasi belajar pesrta didik.

Kinerja guru merupakan faktor dominan yang mempengaruhi prestasi belajar siswa. Oleh karena itu kinerja guru harus senantiasa ditingkatkan dengan cara melakukan supervisi kinerja mengajar guru. Supervisi kinerja mengajar guru teriri dari (1) perencanaan pembelajaran dengan cara mengecek kelengkapan administrasi pembelajaran terutama kesiapan silabus dan rencana pelaksanaan pembelajaran (RPP), (2) pelaksanaan pembelajaran dengan nilai guru dalam mengajar di dalam kelas dengan cara membandingkan langkah-langkah pembelajaran yang telah direncanakan dalam RPPdengan standar yang telah ditetapkan pemerintah dengan kenyataan yang dilakukan oleh guru, (3) penilaian pembelajaran dengan cara melakukan evaluasi terhadap hasil penilaian pembelajaran yang diakukan guru, apakah telah memenuhi ketuntasan minimal atau tidak, serta tingkat keberhasilan pembelajaran yang dilakukan guru dalam kelas. (Junianto, 2013: 307-319).

Berdasarkan uraian di atas kinerja mengajar guru adalah kemampuan seorang guru dan keberhasilan guru dalam melaksanakan tugasnya sebagai pendidik dan pengajar secara optimal dalam proses belajar mengajar untuk mencapai tujuan pembelajaran.

\section{B. Kemampuan Profesional Guru}

Kemampuan guru yang dimaksud adalah potensi guru untuk menguasai, keterampilan dan perilaku yang dimiliki dalam melaksanakan tugas profesionalnya. Yang dimaksud kompetensi professional adalah kemampuan guru dalam penguasaan materi pembelajaran secara luas dan mendalam dalam pelaksanaan proses belajar mengajar untuk menguasai masalah akademik sehingga kompetensi ini dimiliki guru dalam menjalankan tugasnya sebagai pendidik dan pengajar.

Menurut Fathurrohman (2012: 40) Guru professional akan dapat menyelenggarakan proses pembelajaran dan penilaian yang menyenangkan bagi siswa dan guru, sehingga dapat mendorong tumbuhnya kreativitas belajar pada diri siswa. Pemilihan pembelajaran yang tepat akan sangat menentukan minat dan partisipasi siswa dalam pembelajaran. Melalui model pembelajaran yang tepat diharapkan siswa tidak hanya dapat pengetahuan, namun juga memiliki kesan yang mendalam tentang materi pembelajaran, sehingga dapat mendorong siswa untuk mengimplementasikan konsep nilai-nilai yang terkandung dalam mata pelajaran dalam kehidupan sehari-hari.

Parkay (Darwin, 2011: 29) menyebutkan bahwa ada salah satu lembaga pengembang sertifikasi guru yaitu Praxis Series mengembangkan standar professional guru yang berhubungan dengan keterampilan mengajar yaitu:

1) Perencanaan dan Persiapan

Dengan indikator sebagai berikut:

a) Menunjukkan pengetahuan tentang konten dan pedagogi

b) Menunjukkan pengetahuan siswa

c) Memilih tujuan instruksi

d) Menunjukkan pengetahuan tentang sumber belajar

e) Mendesain instruksi yang logis

2) Suasana Kelas

Dengan indikator sebagai berikut:

a) Menciptakan lingkungan dengan saling menghargai dan hubungan baik

b) Mengembang budaya untuk belajar

c) Menangani prosedur kelas

d) Menangani perilaku siswa

e) Manata ruang fisik

3) Insruksi

Dengan indikator sebagai berikut:

a) Berkomunikasi secara jelas dan akurat

b) Menggunakan teknik bertanya dan diskusi

c) Melibatkan siswa dalam belajar

d) Memberikan umpan balik bagi siswa

e) Menunjukkan fleksibilitas dan responsiveness

4) Tanggung jawab professional

Dengan indikator sebagai berikut:

a) Merenungkan pengajaran

b) Membuat catatan yang akurat

c) Berkomunikasi dengan keluarga siswa

d) Memberikan kontribusi pada sekolah

e) Tunbuh dan berkembang secara professional.

Dari uraian di atas maka dapat disimpulkan bahwa guru professional yaitu guru yang meiliki kemampuan dalam bidang pendidikan dan keahlian di bidang studi yang diajarkan dan mampu memotivasi siswa untuk mengoptimalkan potensinya dalam rangka mencapai standar pendidikan yang ditetapkan. Dalam hal ini peneliti menggunakan pendapat dari Parkay karena telah mencakup semua kemampuan yang harus dimiliki oleh seorang guru.

\section{Motivasi Kerja}

Motivasi kerja terdiri dari dua kata yaitu motivasi dan kerja. Menurut Hasibuan (2003: 95), motivasi berasal dari kata dasar motif, yang 
mempunyai arti suatu perangsang, keinginan dan daya penggerak kemauan bekerja seseorang. Motivasi adalah pemberian daya penggerak yang menciptakan kegairahan kerja seseorang agar mereka mau bekerjasama dengan efektif dan terintegrasi dengan segala daya upayanya untuk mencapai kepuasan.

Menurut Robbins (2001: 166), motivasi adalah kesediaan untuk mengeluarkan tingkat upaya yang tinggi untuk tujuan organisasi yang dikondisikan oleh kemampuan upaya itu dalam memenuhi beberapa kebutuhan individual. Kebutuhan terjadi apabila tidak ada keseimbangan antara apa yang dimiliki dan apa yang diharapkan. Dorongan merupakan kekuatan mental yang berorientasi pada pemenuhan harapan dan pencapaian tujuan. Dan tujuan adalah sasaran atau hal yang ingin dicapai oleh seseorang individu.

Teori Herzberg mengembangkan teori isi yang dikenal sebagai teori motivasi dua faktor. Kedua faktor tersebut disebut dissatisfier-satisfier, motivator higiane atau faktor ekstrinsik-intrinsik, tergantung dengan pembahasan teori. Teori dua faktor Frederick Herzberg merupakan teori yang didalamnya terdapat dua faktor, faktor intrinsik dan ekstrinsik. Faktor intrinsik ini berkaitan dengan kepuasan kerja, sedangkan faktor ekstrinsik berkaitan dengan ketidakpuasan kerja. Teori dua faktor ini juga sering disebut dengan teori motivasi higienis.

Tabel 2.1

Teori Dua-Faktor Herzberg

\begin{tabular}{|c|c|}
\hline $\begin{array}{c}\text { Faktor Motivasi } \\
\text { (Intrinsik) }\end{array}$ & $\begin{array}{c}\text { Faktor Motivasi } \\
\text { (Ekstrinsik) }\end{array}$ \\
\hline $\begin{array}{l}\text { 1. Prestasi } \\
\text { 2. Penghargaan } \\
\text { 3. Pekerjaan itu } \\
\text { sendiri } \\
\text { 4. Tanggung jawab } \\
\text { 5. Pertumbuhan dan } \\
\text { perkembangan }\end{array}$ & $\begin{array}{l}\text { 1. Supervisi } \\
\text { 2. Kondisi kerja } \\
\text { 3. Hubungan } \\
\text { interpersonal } \\
\text { 4. Bayaran dan } \\
\text { keamanan } \\
\text { 5. Kebijakan } \\
\text { perusahaan/ } \\
\text { organisasi }\end{array}$ \\
\hline
\end{tabular}

Sumber: Usman (2010: 260)

Dari pengertian diatas dapat disimpulkan bahwa yang dimaksud motivasi kerja adalah sesuatu yang dapat menimbulkan semangat atau dorongan bekerja individu atau kelompok terhadap pekerjaan untuk mencapai tujuan. Motivasi kerja guru adalah kemauan atau kebutuhan guru dalam melaksanakan tugasnya dan memberikan energi untuk bekerja untuk mencapai tujuan tertentu.

\section{METODE PENELITIAN}

Penelitian ini menggunakan pendekatan kuantitatif untuk mengetahui seberapa besar pengaruh kemampuan professional guru dan motivasi kerja terhadap kinerja mengajar guru sekolah dasar di Kota Cimahi. Adapun metode penelitian dalam penelitian ini menggunakan metode desktiptif untuk membuat deskripsi, gambaran mengenai fakta-fakta, sifat serta hubungan yang terjadi antara variabel dependen dan independen. Data penelitian diambil menggunakan angket di 35 sekolah dasar kota cimahi

Teknik analisis data yang digunakan pada penelitian ini yaitu analisis korelasi sederhana, analisis regresi sederhana, analisis korelasi ganda, analisis regresi ganda, koefisien determinasi, uji t, dan uji F. Pengolahan analisis data pada penelitian ini menggunakan bantuan SPSS Ver.17 untuk membantu penulis dalam menghitung data.

\section{HASIL PENELITIAN}

\section{Hasil Analisis Data Deskriptif}

Berikut ini hasil analisis data deskriptif pada setiap variabel penelitan: a. Kinerja mengajar guru 


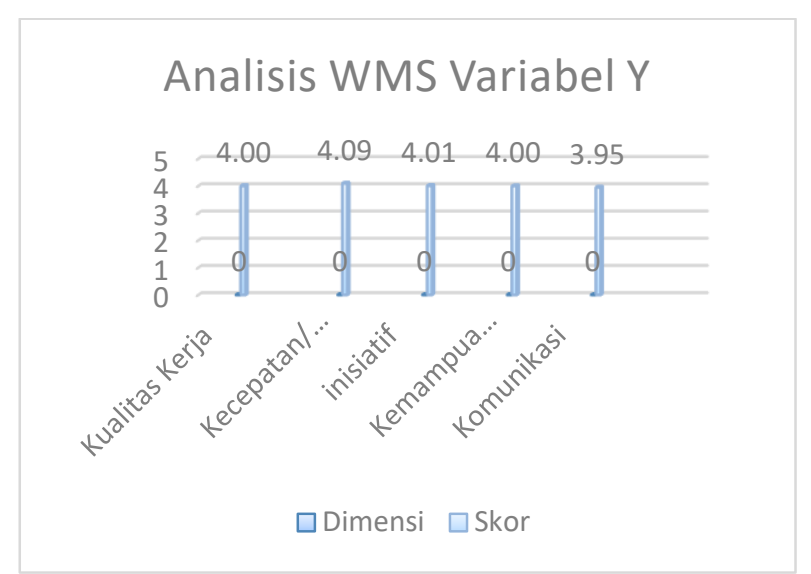

Gambar 1.

Grafik rata-rata kinerja mengajar guru

b. Kemampuan Profesional guru

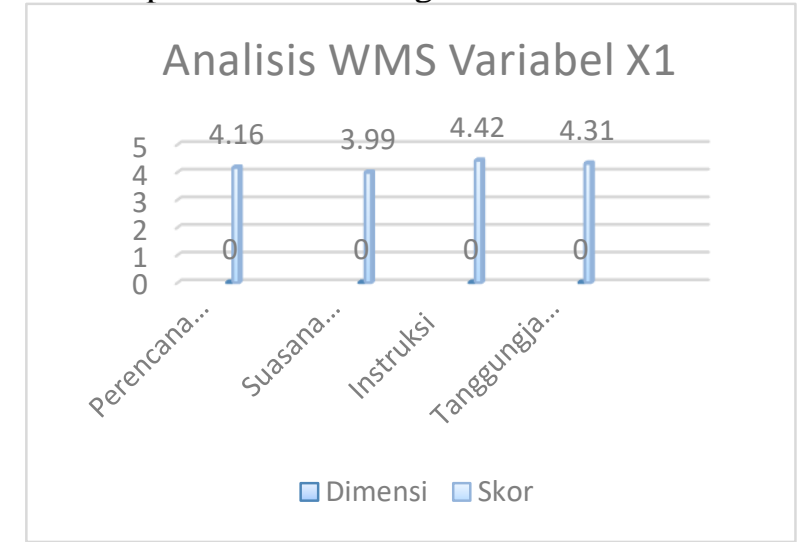

Gambar 2. Grafik rata-rata kemampuan professional guru

c. Motivasi kerja

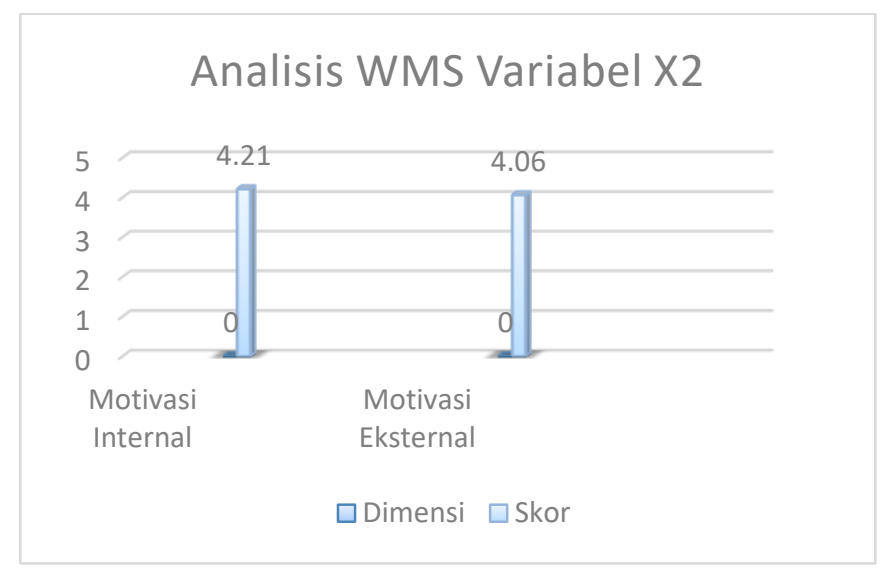

Gambar 3. Grafik rata-rata motivasi kerja

\section{Hasil Pengujian Hipotesis}

Berikut ini rangkuman hasil analisis data pada variabel kemampuan professional guru $\left(\mathrm{X}_{1}\right)$, Motivasi kerja $\left(\mathrm{X}_{2}\right)$, dan kinerja menagajar guru (Y) :

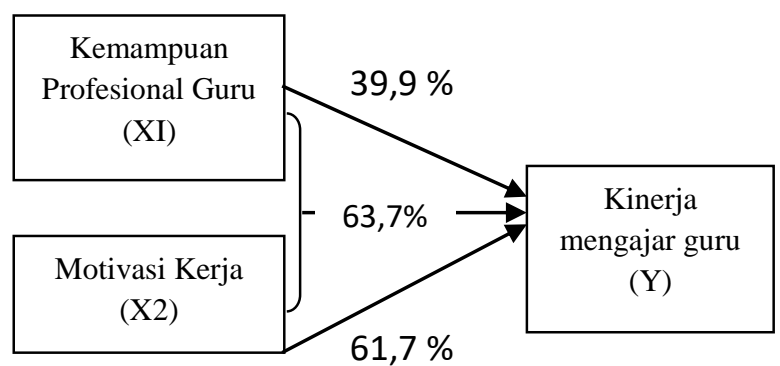

Gambar 4. Rangkuman Analisis Data

\section{PEMBAHASAN}

\section{A. Deskripsi Kemampuan Profesional Guru}

Kemamuan profesional guru berada pada kategori sangat tinggi. Kemampuan profesional guru merupakan potensi guru untuk menguasai, keterampilan dan perilaku yang dimiliki dalam melaksanakan tugas profesionalnya. Yang dimaksud kompetensi professional adalah kemampuan guru dalam penguasaan materi pembelajaran secara luas dan mendalam dalam pelaksanaan proses belajar mengajar untuk menguasai masalah akademik sehingga kompetensi ini dimiliki guru dalam menjalankan tugasnya sebagai pendidik dan pengajar.

Menurut Fathurrohman (2012: 40) dalam penelitiannya menyatakan bahwa Guru professional akan dapat menyelenggarakan proses pembelajaran dan penilaian yang menyenangkan bagi siswa dan guru, sehingga dapat mendorong tumbuhnya kreativitas belajar pada diri siswa.
Pemilihan pembelajaran yang tepat akan sangat menentukan minat dan partisipasi siswa dalam pembelajaran. Melalui model pembelajaran yang tepat diharapkan siswa tidak hanya dapat pengetahuan, namun juga memiliki kesan yang mendalam tentang materi pembelajaran, sehingga dapat mendorong siswa untuk mengimplementasikan konsep nilai-nilai yang terkandung dalam mata pelajaran dalam kehidupan sehari-hari.

Dari keempat dimensi kemampuan profesional guru, kemampuan mengelola suasana kelas menjadi dimensi yang paling rendah, artinya bahwa guru belum cukup baik dalam mengelola kelas yang terdiri dari Menciptakan lingkungan yang baik, Mengembangkan budaya untuk belajar, Menangani perilaku siswa, Menangani prosedur kelas dan Menata ruang fisik. Pengaturan kelas atau pengelolaan kelas adalah upaya yang 
dilakukan oleh guru untuk memberi kebebasan untuk siswa melekukan berbagai aktivitas sesuai dengan zang mereka inginkan.

\section{B. Deskripsi Motivasi Kerja}

Motivasi kerja berada pada kategori sangat tnggi. Motivasi kerja menurut Hasibuan (2003: 95), motivasi berasal dari kata dasar motif, yang mempunyai arti suatu perangsang, keinginan dan daya penggerak kemauan bekerja seseorang. Motivasi adalah pemberian daya penggerak yang menciptakan kegairahan kerja seseorang agar mereka mau bekerjasama dengan efektif dan terintegrasi dengan segala daya upayanya untuk mencapai kepuasan. Menurut hal ini didukung dengan pernyataan Amirullah (2002: 146) dalam penelitiannya bahwa motivasi kerja adalah kondisi yang berpengaruh membangkitkan, mengarahkan dan memelihara perilaku yang berhubungan dengan lingkungan kerja.

Motivasi kerja guru dalam mengajar dipengaruhi oleh motivasi internal dan motivasi eksternal, dalam penelitian ini motivasi eksternal menjadi dimensi yang paling rendah. Motivasi eksternal terdiri dari Hubungan Interpersonal, Bayaran/Gaji, Supervisi, Kondisi Kerja, dan Kebijakan Organisasi. Jika dianalisis lebih jauh, gaji/bayaran merupakan indikator yang paling rendah hal ini disebabkan karena guru merasa bahwa gaji yang diberikan oleh pemerintah belum sesuai dengan kebutuhan dalam kehidupan sehariharinya sehingga perlu peningkatan dalam hal gaji.

\section{Deskripsi Kinerja Mengajar Guru}

Kinerja mengajar guru berada pada kategori tinggi. Kinerja mengajar guru adalah kemampuan seorang guru dan keberhasilan guru dalam melaksanakan tugasnya sebagai pendidik dan pengajar secara optimal dalam proses belajar mengajar untuk mencapai tujuan pembelajaran. Melihat hasil penelitian, dari beberapa dimensi yang ada, dimensi komunikasi merupakan dimensi memiliki rata-rata paling rendah, artinya guru-guru di SD Kota Cimahi belum memahami dan menyelenggarakan administrasi sekolah dengan baik dan beum memahami dan dapat menafsirkan hasil-hasil penelitian untuk meningkatkan kualitas pembelajaran dengan baik.

Kinerja mengajar akan sangat menentukan kualitas hasil pendidikan, seperti yang dikemukakan Mulyasa (2007:5) yang menyatakan bahwa upaya perbaikan apapun yang dilakukan untuk meningkatkan kualitas pendidikan tidak akan memberikan sumbangsih yang signifikan tanpa didukung oleh guru yang berkualitas.

\section{Pengaruh Kemampuan Profesonal Guru Terhadap Kinerja Mengajar Guru}

Dari hasil penelitian, terdapat pengaruh antara kemampuan profesional guru terhadap kinerja mengajar guru di SD Kota Cimahi sebesar 0,399 atau $39,9 \%$ yang tergolong sedang dan sisanya $60,1 \%$ dipengaruhi oleh hal lain yang tidak di teliti dalam penelitian ini. Banyak faktor yang mempengaruhi kinerja mengajar seorang guru salah satunya adalah faktor kemampuan atau kompetensi. Grote (1996:87) dalam penelitiannya menyatakan bahwa kompetensi ada karakteristik mendasar dari individu yang berhubungan dengan efektif tidaknya seseorang dalam bekerja. Agar guru menunjukkan kinerja mengajarnya maka guru harus memiliki kemampuan atau kompetensi terutama kamampuan profesional sebagai seorang pendidik. Sehingga dengan demikian, untuk meningkatkan kinerja mengajar guru di Sekolah Dasar Kota Cimahi perlu dilakukan peningkatan kemampuan profesional guru.

Castetter (Sagala, 2006:4) menyatakan bahwa kualitas proses belajar mengajar sangat dipengaruhi oleh kemampuan profesional guru. Seorang guru akan dapat melaksanakan tugasnya dengan apabila memiliki pengetahuan dan keterampilan serta wawasan yang luas dalam bidangnya. Hal ini didasarkan dengan pemikiran bahwa seorang guru akan dapat melaksanakan tugasnya dengan baik apabila memiliki pengetahuan dan keterampilan serta wawasan yang luas dalam bidangnya. Untuk meningkatkan kinerjanya, guru harus selalu berusaha tepat waktu, menggunakan metode dan strategi pembelajaran dengan tepat, serta mengikuti seminar atau pelatihan sehingga dapat meningkatkan kualitas pembelajaran.

Hal ini diperkuat juga dengan pernyataan Ditjen PMPTK (2008:6) Kompetensi Profesional yaitu kemampuan yang harus dimiliki guru dalam perencanaan dan pelaksanaan proses pembelajaran. Ditjen PMPTK (2008:21) berkaitan dengan kinerja guru, Kinerja guru mempunyai spesifikasi tertentu. Kinerja guru dapat dilihat dan diukur berdasarkan spesifikasi/kriteria kompetensi yang harus dimiliki oleh setiap guru. Wujud perilaku yang dimaksud adalah kegiatan guru dalam proses pembelajaran yaitu bagaimana seorang guru merencanakan pembelajaran, melaksanakan kegiatan pembelajaran, dan menilai hasil belajar. Pernyataan ini menjelaskan bahwa kompetensi profesional merupakan sebuah persyaratan yang 
harus dipenuhi terlebih dahulu oleh seorang guru sebelum melaksanakan tugasnya dalam kegiatan pembelajaran.

\section{E. Pengaruh Motivasi Kerja Terhadap Kinerja Mengajar Guru}

Dari hasil penelitian, terdapat pengaruh antara motivasi kerja guru terhadap kinerja mengajar guru di SD Kota Cimahi sebesar 0,617 atau $61,7 \%$ dan sisanya dipengaruhi oleh faktor lain yang tidak diteliti dalam penelitian ini. Hal ini juga di dukung oleh Cahyono (Solihin, 2007:37) yang menyatakan bahwa kinerja mengajar guru dipengaruhi oleh faktor internal dan eksternal. Faktor internal mencakup motivasi, kompetensi dan kepuasan kerja.

Motivasi sendiri dalam eksistensi motivasi terbagi dua yaitu intrinsik dan ekstrinsik. Motivasi ekstrisik merupakan motivasi yang muncul disebabkan oleh faktor eksternal, misalnya yang berhubungan dengan faktor ekonomi (Hunt, 1979; Siagian, 1995; Davis, 1981 dan Newcomb, 1989), seperti gaji, honorarium atau insentif-insentif lain seperti harapan untuk cepat naik pangkat, untuk mendapatkan pujian dan kesan yang baik atau sebaliknya untuk menghindari teguran dan penilaian jelek dari atasan.

\section{F. Pengaruh Kemampuan Profesional Guru dan Motivasi Kerja Terhadap Kinerja Mengajar Guru}

Dari hasil penelitian, terdapat pengaruh antara kemampuan profesional guru dan Motivasi kerja guru terhadap kinerja mengajar guru di SD Kota Cimahi sebesar $63,7 \%$ hal ini berati bahwa kemampuan profesional guru dan motivasi kerja sama-sama memberikan pengaruh yang sangat signifikan dalam peningkatan kinerja mengajar guru.

\section{SIMPULAN DAN REKOMENDASI}

\section{Simpulan}

Berdasarkan hasil penelitian dan analisis data yang telah diuraikan pada bab sebelumnya, maka penulis dapat menarik kesimpulan sebagai berikut:

a. Kinerja Mengajar guru di Sekolah Dasar Kota Cimahi berada pada kategori sangat tinggi hal ini berarti bahwa guru secara Kualitas kerja, Kecepatan/Ketepatan, Inisiatif, Kemampuan Kerja dan Komunikasi telah dilakukan dengan baik. Rata-rata yang paling tinggi adalah dimensi Ketepatan/kecepatan dan terendah adalah dimensi tingkat komunikasi.

b. Kemampuan profesional guru di Sekolah Dasar Kota Cimahi berada pada kategori sangat tinggi. artinya bahwa guru secara Perencanaan dan persiapan, Suasana kelas, Instruksi dan tanggungjawab dan profesional telah dilakukan dengan baik. Rata-rata yang paling tinggi adalah dimensi instruksi dan terendah adalah dimensi tanggungjawab dan Profesional.

c. Pengaruh antara kemampuan profesional guru terhadap kinerja mengajar guru di SD Kota Cimahi signifikan dan pengaruhnya tergolong sedang. Secara praktis faktor yang menyebabkan pengaruhnya sedang antara lain guru masih kurnag dalam hal tanggungjawab dan profesional yang meliputi merenungkan pengajaran, membuat catatan yang akurat, berkomunikasi dengan orang tua siswa, memberikan kontribusi kepada sekolah dan mampu tumbuh dan berkembang secara terus menerus. Kompetensi profesional terutama membuat catatan yang akurat masih belum optimal dilakukan karena guru di sekolah tidak hanya mengajar satu dua murid malainkan puluhan murid sehingga ini berpengaruh kepada penilaian kinerja mengajar guru yang masih terbatas pada penilaian secara angka bukan pada deskripsi.

d. Pengaruh antara motivasi kerja guru terhadap kinerja mengajar guru di SD Kota Cimahi memiliki pengaruh yang signifikan dan berada pada kategori tinggi. Hal ini karena motivasi eksternal yang belum sepenuhnya mendorong guru untuk memiliki kinerja mengajar yang unggul, salah satunya adalah faktor gaji, meskipun guru telah mendapatkan sertifikasi tetapi untuk guru di Sekolah dasar Cimahi masih dirasa kurang sengga ini berpengaruh kepada kinerja mengajarnya.

e. Pengaruh antara kemampuan profesional guru dan Motivasi kerja guru terhadap kinerja mengajar guru di SD Kota Cimahi berada pada kategori tinggi yang berarti keduanya memiliki pengaruh yang signifikan dan positif. Hipotesis yang yang peneliti ajukan di terima artinya bahwa terdapat pengaruh yang signifikan antara antara kemampuan profesional guru dan Motivasi kerja guru terhadap kinerja mengajar guru di SD Kota Cimahi Persamaan regresi yang diperoleh linier artinya semakin tinggi Kemampuan profesional guru dan motivasi kerja guru maka akan semakin tinggi juga kinerja mengajar guru di Sekolah Dasar Kota Cimahi. 


\section{Rekomendasi}

Berdasarkan simpulan hasil penelitian di atas maka penulis memberikan saran sebagai berikut:

a. Hasil penelitian mengungkapkan bahwa kinerja mengajar guru secara umum sudah tinggi, namun tidak hanya tinggi melainkan harus ditingkatkan lagi menjadi sangat tinggi dan unggul terutama dalam hal komunikasi dalam menafsirkan hasil-hasil penelitian untuk peningkatan kualitas pembelajaran. Rekomendasinya adalah guru harus dilibatkan dan melibatkan diri dalam berbagai penelitian yang dapat meningkatkan kualitas belajar sehingga hasilnya dapat diterapkan dalam pembelajaran sehari-hari.

b. Dimensi kemampuan profesional guru yang paling kecil adalah mengatur sdan membangun suasana kelas, sehingga guru perlu dilaih dan dibina dalam membuat suasan kelas yang lebih menyenangkan untuk anak belajar dan menerima pelajaran.

c. Ada sebagian guru yang merasa dari sisi motivasi eksternal terutama berkaitan dengan gaji/bayaran masih dirasa kurang cukup sehingga harus ada penyesuaian gaji/bayaran dengan kebutuhan guru di lapangan.

d. Peneliti selanjutnya

Agar lebih fokus peneliti selanjutnya hendaknya melakukan penelitian kemampuan profesional guru, motivasi kerja dan kinerja mengajar secara kuanlitatif dan banyak dimensi dari kinerja mengajar yang harus dikaji lebih mendalam di sekolah atau madrasah, juga mendalami faktor-faktor lain yang mempengaruhi kinerja mengajar guru di sekolah untuk dikaji lebih lanjut serta melakukan penelitian di sekolah dan dikomparasikan hasilnya dengan penelitian ini.

\section{DAFTAR PUSTAKA}

Amirullah, dan Hanafi, Rindyah. (2002). Pengantar Manajemen. Yogyakarta: Graha Ilmu.Arikonto , Suharsimi. 2006. Menejemen Penelitian. Edisi revisi. Jakarta ; Rineka Cipta

DEPDIKNAS RI. UURJ No. 20. (2003). Sistem Pendidikan Nasional. Jakarta: DEPDIKNAS RI Jakarta. Diknas, Alat Penilaian Kemampuan Guru. 2003

Hasibuan, Malayu SP. (2003). Organisasi Dan Motivasi. Jakarta: PT Bumi Aksara.

Mohammad Natsir. (2003). Metode Penelitian. Jakarta: Ghalia

Mulyasa. (2007). Standar Kompetensi dan Sertifikasi Guru. Bandung: PT Remaja Rosdakarya.

NCESPPMP. (2013). Pengaruh Keterampilan Kepemimpinan Kepada Sekolah dan Motivasi Kerja Guru Terhadap Kinerja SMP Negeri Sub Rayon 03 Kab Jepara. Jurnal Manajemen Pendidikan. Vol 2, No 1

Robert Bacal. (2001). Performance Management. Terj.Surya Darma dan Yanuar Irawan. Jakarta : PT Gramedia Pustaka Utama, 2001

Sagala, Saiful. (2006). Kemampuan Profesional Guru dan Tenaga Kependidikan. Bandung: Alfabeta

Sudjana. (2002). Metode Statistik. Bandung: Transito.

Sudjana, Nana. (2004). Dasar-Dasar Proses Belajar Mengajar. Bandung: Sinar Baru Algensindo
Sukardi, (2013). Metodologi Penelitian Pendidikan (Kompetensi dan Prakteknya). Jakarta: Bumi Aksara

Suharsaputra, Uhar. (2012). Metode Penelitian Kuantitatif, Kualitatif, dan Tindakan. Bandung: PT Refika Aditama

Solihin, Ahmad. (2007). Pengaruh Perilaku Kepemimpinan Transformasional Kepala Sekolah Dan Kompetensi Pedagogik Terhadap Kinerja Mengajar Guru Di SD Kota Bandung. Tesis. Bandung: Universitas Pendidikan Indonesia.

Siagian Sondang.P. (1995). Teori Motivasi dan Aplikasinya. Rineka Cipta. Jakarta

UNDANG-UNDANG REPUBLIK INDONESIA Nomor 20 tahun 2003 tentang system pendidikan nasional

Uzer, Moh Usman. 2005. Menjadi Guru Profesional. Bandung: PT Remaja Rosdakarya.

Uno, Hamzah, dan Nina. 2012. Teori Kinerja dan Pengukurannya. Jakarta: Bumi Aksara

Purwanto. 2010. Metodologi Penelitian Kuantitatif untuk Psikologi dan Pendidikan. Yogjakarta: Pustaka Pelajar 